\title{
Is employment growth affected by the introduction of broadband services? Evidence from firms in Ireland
}

\author{
Philip Carthy ${ }^{1,2}$ - Seán Lyons ${ }^{1,2 *}$ \\ ${ }^{1}$ Economic and Social Research Institute, Dublin, Ireland \\ ${ }^{2}$ Trinity College Dublin, Dublin, Ireland
}

Received: 27 July 2018

Revised: 15 January 2019

Accepted: 16 January 2019

\begin{abstract}
This paper examines the effects of deploying digital subscriber line (DSL) broadband on job creation within existing firms. We use spatial information on broadband and firm locations, exploiting geographical and temporal variation in broadband availability in Ireland during 2007-2014. This is linked to a panel of firm-level data on employment and other characteristics. Econometric models are used to explore the relationship between DSL and employment over time and across local economic and industry contexts. We also investigate whether effects might vary depending upon local educational attainment. We find little evidence of a general effect of DSL roll-out on employment in Irish firms.
\end{abstract}

Keywords: broadband; employment growth; Ireland JEL Classification Codes: D22, L96, R12

\section{Introduction}

The provision of high-speed internet services necessitates significant capital investment, which is often publicly funded. It is thus important that research strives to provide clarity on the potential economic benefits of broadband diffusion. In a recent survey of the literature, Bertschek et al. (2015) highlight that the expansion of broadband has been associated with various economic benefits including GDP growth, increased firm presence, and productivity gains. There is, however, notable heterogeneity in these findings, with many results sensitive to context.

The economic gains from the introduction of broadband may also manifest as changes in

\footnotetext{
*Corresponding authors. E-mail: sean.lyons@esri.ie.

Citation: Carthy, P. and Lyons, S. (2019) Is employment growth affected by the introduction of broadband services? Evidence from firms in Ireland, Economics and Business Letters, 8(1), 41-42.
}

DOI: $10.17811 / \mathrm{ebl} \cdot 8.1 .2019 .41-52$ 
local employment growth. This is reflected in a selection of empirical studies including Czernich et al. (2011) and Ivus and Boland (2015). The former analyse the effect of digital subscriber line (DSL) availability on the German municipality level unemployment rate. A positive but quantitatively small association is identified in OLS regressions but the effect is not robust to modelling with instrumental variables and thus cannot be considered causal. The latter find that DSL roll-out promoted both aggregate employment growth and average wages across rural Canada. This effect was, however, limited to services industries and was most pronounced among sub-sectors which could be classified as "IT-intensive". In urban areas, broadband rollout showed signs of curtailing growth, suggesting that the technology was of greatest benefit to service firms who needed to overcome geographical constraints in their business models.

If broadband availability does affect employment, the effect may be heterogeneous across firms and local economic landscapes. Education is likely a mediating factor. Broadband access may be complementary to highly skilled labour but act as a substitute to positions requiring lower skill levels (Akerman et al. 2015). In order to test this "skill complementarity" hypothesis, some studies present empirical models which interact broadband availability with the proportion of the local population who have obtained a degree or higher level of education. Atasoy (2013) and Kolko (2012) are two examples. The former identifies a positive effect of DSL on U.S. county-level employment that varies significantly in magnitude across the distribution of the education proxy. The latter finds that the proportion of degree holders over the age of 25 mediates a positive effect of DSL on employment in the early years of rollout. The effect dissipates in later samples possibly indicating a complementarity between broadband and highly skilled labour and specialised knowledge only when the technology was new.

The current research contributes to what remains a relatively sparse literature focusing on the relationship between firm-level employment and DSL broadband. DSL is of particular research interest as it was the predominant technology used by SMEs in Ireland who had access to the internet during the early years of broadband roll-out. We use detailed information on the rollout of DSL in the Republic of Ireland to exploit geographical and temporal variation in broadband availability between the years 2007-2014. By combining this information with a panel of geocoded firm-level employment data, we are able to study broadband diffusion micro-econometrically with the firm as the unit of analysis. Such dis-aggregation is uncommon to date. We also contribute to the existing literature by further investigating the potential variation of the economic effects of broadband across firm size, sector and type. Furthermore, we empirically test the skill complementarity hypothesis in the case of Ireland by studying the interactions between broadband diffusion and a spatial measure of human capital.

\section{Methods}

For research purposes, DSL is conventionally characterised in one of two ways: availability or adoption. We focus on availability. This choice is made for two reasons. First, despite a potential role for demand response to the new technology, it is the presence of the broadband infrastructure that is the essential enabling factor in any link between DSL and employment. Second, extending the availability of high-quality broadband access to underserved regions has, to date, been the primary focus of most public policies that aim to improve DSL penetration. We allow for potential time delays between the date on which DSL services are initially enabled and that by which firms have effectively embedded the new technology into their business processes by using a lagged representation of DSL availability. Specifically, DSL enters our empirical models as the share of the previous year for which DSL services were available to a given firm.

To investigate whether local educational attainment moderates the effect of DSL on employment, we use two strategies. First, following the convention of Kolko (2012) and Atasoy (2013) we interact DSL availability with the proportion of local residents who have obtained a univer- 
sity degree or higher level of education. Second, we split our sample at the median local educational attainment among firms that became DSL enabled during our sample to perform subgroup analyses.

Our dependent variable measures annual proportional change in the number of employees at each firm. By representing the absolute change as a proportion of total employment in the previous year, we account for the likelihood that the magnitude of employment changes vary systematically by firm size. In order to fully encompass all changes into a single measure, we use weighted full-time equivalent (FTE) employment. The variable weights every two part-time workers in our data as a single full-time employee.

We thus estimate a set of fixed effects panel regressions of the following form:

$$
\Delta Y_{i t}=\alpha+\beta_{1} D S L_{i t-1}+\beta_{2}\left(D S L_{i t-1} \times D E G\right)+\beta_{3} X_{i t}+\eta_{i}+\epsilon_{i t}
$$

$\Delta Y_{i t}$ denotes proportional change in FTE employment for firm $i$ in time $t$ with respect to time $t-1$. $D S L_{i t-1}$ is our variable measuring broadband availability. $D E G$ is the proportion of the local Electoral Division (ED) who have obtained a university degree or higher level of education. $X_{i t}$ is a vector of other relevant controls including year effects that account for unobserved time-specific factors, $\eta_{i}$ is a firm fixed effect which captures time-invariant heterogeneity among firms and $\epsilon_{i t}$ is an error term such that $\epsilon_{i t} \sim \operatorname{IID}\left(0, \sigma_{\epsilon}^{2}\right)$. The interaction term is, naturally, omitted in education subgroup analyses.

While there are some concerns in the literature that the relationship between DSL and employment could suffer from endogeneity because of reverse causal or omitted factor mechanisms (Czernich 2014; Ivus and Boland 2015; Kolko 2012), they are not shared here. Central to this are three points: First, our dependent variable is an annualised flow in employment. We argue that, even under a reverse causality scenario, the commercial (or policy) decision to deploy DSL to a particular region is likely to be influenced more by the local population density than expected future employment growth rates. Second, as noted, we characterise DSL diffusion by its availability rather than its adoption. It is more plausible that omitted firm-level factors drive changes in broadband adoption than it is that they affect the national pattern of DSL deployment. Third, we lag DSL availability by a year in our regressions, so the model relates current employment growth to past DSL levels. Nevertheless, we suggest that the results reported in this paper should be interpreted cautiously and do not support strong claims about causality.

\section{Data}

The data used combines information from three sources. The first is the Annual Employment Survey (AES), carried out by the Department of Business, Enterprise and Innovation (DBEI) within the Irish Government. The dataset is a firm-level panel created from an annual census of all manufacturing and service firms under the remit of the Irish State's enterprise development agencies. We consider employment changes for existing firms in the years 2007-2014. As such, firm entries to or exits from the dataset are excluded. ${ }^{1}$ Observations for which the dependent variable is greater than 3 standard deviations above its mean are considered to be outliers and are also excluded. The effective sample thus comprises of 40,693 firm-year observations. For each observation, the AES provides the geocoded location of the firm, a NACE Rev.2 code which outlines the sector in which the firm operates, whether the firm is under Irish or foreign ownership as well as the number of full and part-time workers employed. Figure 1 plots employment changes aggregated by our DSL availability variable over time. While job losses are

\footnotetext{
${ }^{1}$ Where zero FTE employees are reported for a single year during a period of sustained employment, this is assumed to be an error. FTE employment is imputed as the mean of its value from the preceding and following years.
} 
observed in years that coincide with the global recession, the overall trend does not appear to differ significantly by DSL status. More detailed descriptive statistics appear in Table 1.

Figure 1. Aggregate Changes in Employment by Lagged DSL Status.

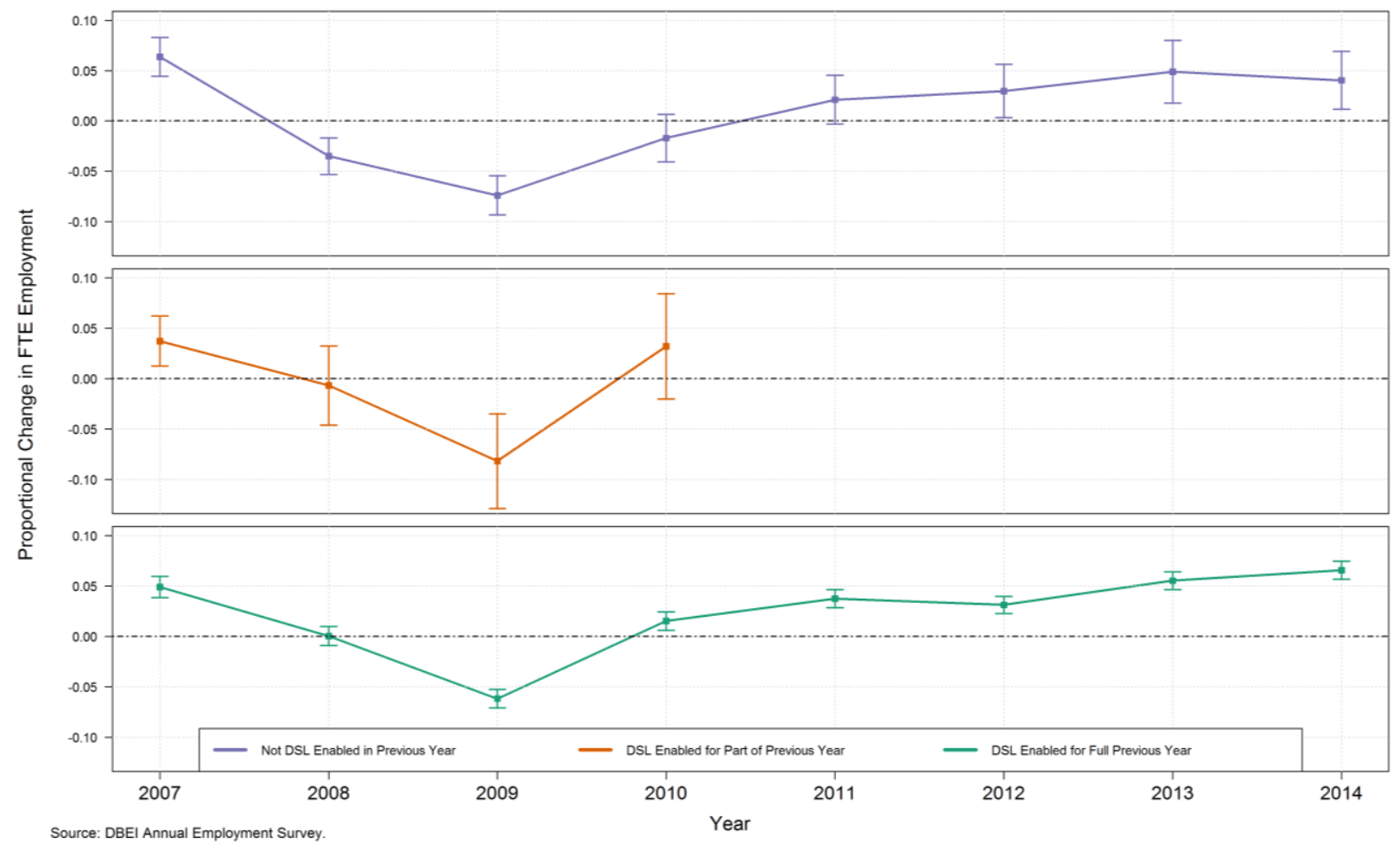

Note: The series in the centre panel is incomplete in order to preserve firm anonymity. Error bars represent $95 \%$ confidence intervals.

Table 1. Descriptive statistics.

\begin{tabular}{|c|c|c|c|c|c|c|c|c|c|}
\hline & \multicolumn{9}{|c|}{ Proportional Change in FTE Employment } \\
\hline & \multicolumn{3}{|c|}{ Full Sample } & \multicolumn{3}{|c|}{$\begin{array}{l}\text { Below Median } \\
\text { Education }\end{array}$} & \multicolumn{3}{|c|}{$\begin{array}{c}\text { Above Median } \\
\text { Education }\end{array}$} \\
\hline & $\mathrm{N}$ & Mean & SD & $\mathrm{N}$ & Mean & SD & $\mathrm{N}$ & Mean & SD \\
\hline \multicolumn{10}{|l|}{ NACE Rev. 2 Sub-Sector } \\
\hline Agriculture, Forestry \& Fishing (A) & 844 & 0.014 & 0.294 & 416 & 0.017 & 0.300 & 428 & 0.010 & 0.288 \\
\hline Mining and Quarrying $(B)$ & 426 & -0.012 & 0.255 & 221 & -0.002 & 0.250 & 205 & -0.023 & 0.260 \\
\hline Manufacturing (C) & 24,695 & 0.009 & 0.280 & 10,090 & 0.004 & 0.281 & 14,605 & 0.011 & 0.278 \\
\hline Water, Sewage \& Waste Mgmt. (E) & 346 & 0.041 & 0.358 & 91 & -0.016 & 0.339 & 255 & 0.062 & 0.363 \\
\hline Construction $(F)$ & 887 & -0.005 & 0.329 & 348 & -0.010 & 0.320 & 539 & -0.002 & 0.335 \\
\hline Wholesale \& Retail Trade $(G)$ & 796 & 0.001 & 0.269 & 314 & -0.011 & 0.239 & 482 & 0.008 & 0.286 \\
\hline Transportation and Storage $(H)$ & 488 & 0.016 & 0.288 & 346 & 0.029 & 0.292 & 142 & -0.015 & 0.276 \\
\hline Accommos & 277 & -0.002 & 0.379 & 157 & 0.004 & 0.395 & 120 & -0.010 & 0.357 \\
\hline ication $(J)$ & 5,983 & 0.067 & 0.366 & 1,390 & 0.047 & 0.351 & 4,593 & 0.073 & 0.371 \\
\hline Financial \& Insurance Activiti & 426 & 0.081 & 0.258 & 196 & 0.050 & 0.235 & 230 & 0.107 & 0.274 \\
\hline $\begin{array}{l}\text { Professional Scientific \& Technical } \\
\text { (M) }\end{array}$ & 1,492 & 0.056 & 0.361 & 430 & 0.046 & 0.362 & 1,062 & 0.060 & 0.362 \\
\hline Admin. and Support Services (N) & 902 & 0.048 & 0.343 & 351 & 0.041 & 0.349 & 551 & 0.052 & 0.338 \\
\hline Education $(P)$ & 429 & 0.035 & 0.313 & 119 & 0.052 & 0.366 & 310 & 0.029 & 0.291 \\
\hline Health \& Social Work $(Q)$ & 340 & 0.044 & 0.339 & 134 & 0.021 & 0.392 & 206 & 0.060 & 0.299 \\
\hline Arts, Entertainment \& Rec. $(R)$ & 1,174 & 0.019 & 0.374 & 425 & -0.002 & 0.353 & 749 & 0.031 & 0.385 \\
\hline Oth & 933 & 0.000 & 0.330 & 562 & 0.001 & 0.332 & 371 & -0.001 & 0.328 \\
\hline Other* & 255 & 0.031 & 0.423 & 109 & 0.051 & 0.455 & 146 & 0.015 & 0.399 \\
\hline \multicolumn{10}{|l|}{ Firm Ownership Status } \\
\hline Irish Owned & 35,531 & 0.020 & 0.313 & 14,190 & 0.012 & 0.307 & 21,341 & 0.025 & 0.316 \\
\hline Foreign Owned & 5,162 & 0.029 & 0.271 & 1,509 & 0.006 & 0.244 & 3,653 & 0.038 & 0.281 \\
\hline
\end{tabular}




\begin{tabular}{|c|c|c|c|c|c|c|c|c|c|}
\hline DSL Status in Previous Year & & & & & & & & & \\
\hline No DSL & 5,760 & 0.007 & 0.316 & 2,767 & 0.004 & 0.312 & 2,993 & 0.009 & 0.320 \\
\hline DSL Enabled (Part Year) & 1,098 & 0.011 & 0.302 & 548 & 0.000 & 0.294 & 550 & 0.021 & 0.309 \\
\hline DSL Enabled (Full Year) & 33,835 & 0.024 & 0.306 & 12,384 & 0.013 & 0.299 & 21,451 & 0.030 & 0.310 \\
\hline$\overline{\text { Total }}$ & 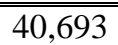 & & & 10 & & & 24,994 & & \\
\hline
\end{tabular}

Source: Department of Business Enterprise and Innovation - Annual Employment Survey.

Note: *Remaining NACE sectors have been aggregated in order to preserve anonymity.

We use spatial information to assess whether broadband services were available to each firm in each year. We combine the firm geocodes with panel data that maps the availability of DSL through the network of fixed-line local telephone exchanges across Ireland. This dataset, which was provided to the authors by the country's primary network operator Eir, includes the locations of all 1,125 local telephone exchanges in the country, the boundaries of the area which each one serves as well as the date on which each was enabled for DSL service. The nature of DSL technology means that service quality is a function of line distance from the exchange and service is not available if the line distance exceeds $5,000 \mathrm{~m}$. In many cases, this means that service remains unavailable in areas of enabled exchanges. We thus define the boundary of enabling as a 5,000m buffer zone around a given exchange or the designated exchange area boundary, whichever is closer to the exchange location. Geographic Information Software (GIS) allows us to map out the effective enabled region under this definition. The results of this GIS process are mapped in Figure 2 while Figure 3 highlights how DSL expansion relates to firms in the AES over time.

Figure 2. Development of DSL enabled regions.

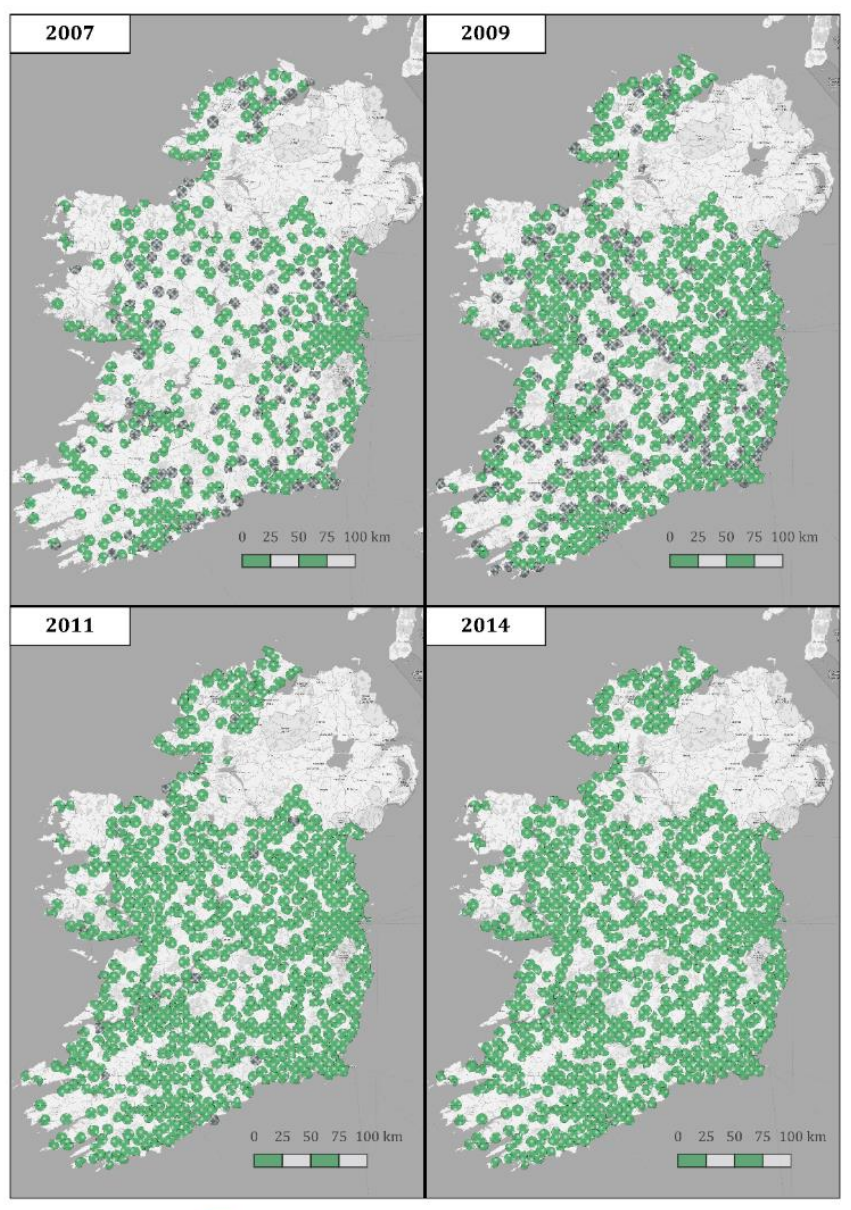

DSL Enabled (Full Year) 
Figure 3. Firms enabled for DSL (2006-2013).

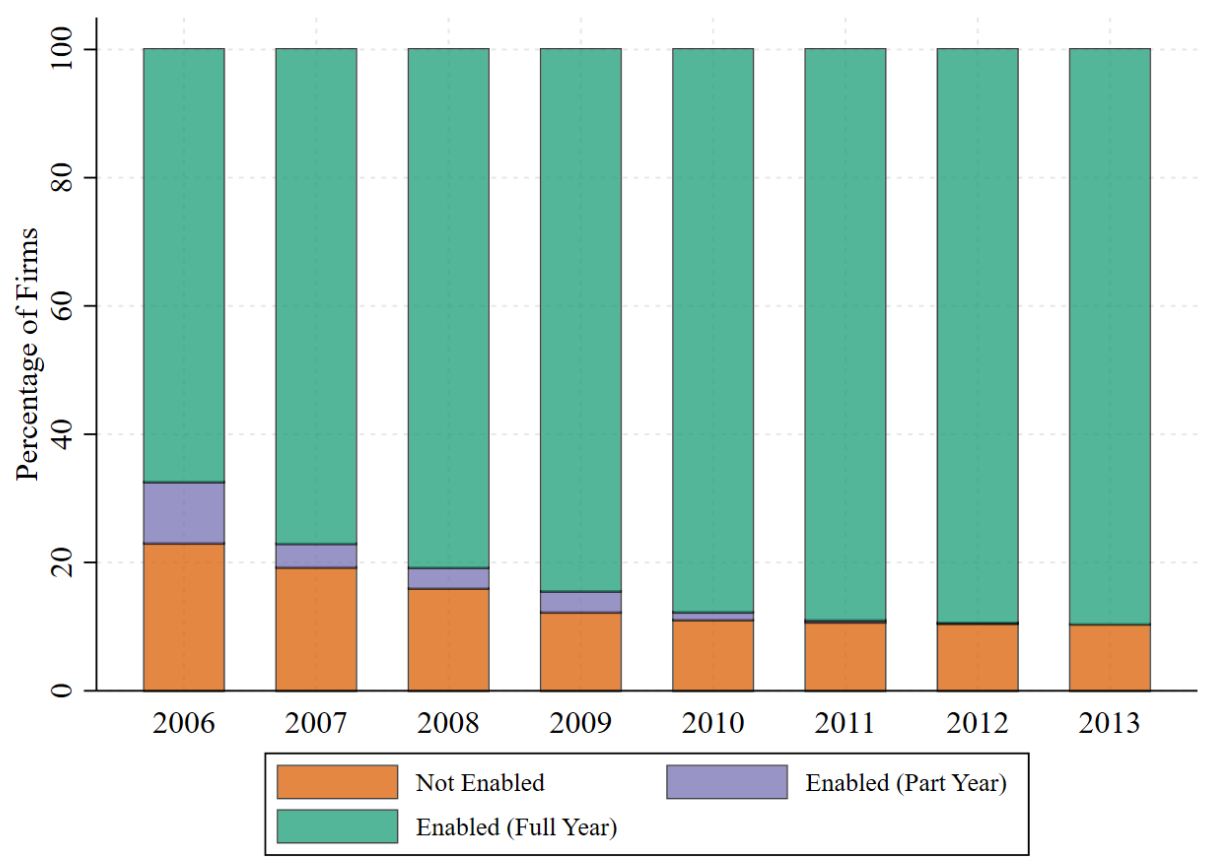

Our final data source, the Census small area population data from 2011, is provided by the Central Statistics Office of Ireland (CSO). From this dataset, we extract the proportion of the population of a given area with a third level degree. The level of aggregation used is the local Electoral Division (ED) of which there are 3,409 in the Republic of Ireland. The geographic area of an ED is the most likely of all available data options to be representative of a local labour market. GIS software is again used to map each firm to its local ED.

Since complete DSL enabling occurred in Ireland's capital, Dublin long before our period of analysis, the county is excluded from the study. Furthermore, Dublin has a uniquely skilled labour market and a density of economic activity great enough to engender spatial agglomerations and knowledge spill-overs not present elsewhere. These fundamental differences further motivate the exclusion.

\section{Results}

Table 2 presents results from our main fixed effects models. We do not find statistically significant effects of DSL availability on employment growth rates. While the sign on the DSL coefficient is positive (as expected) in the full sample specification, statistical significance is only observed at the $10 \%$ level. The coefficient on the interaction between DSL and educational attainment is also not statistically significant. Indeed, when the sample is split by education subgroup, the DSL coefficient is not statistically significant in either sub-sample. The values of the DSL coefficients remain relatively unchanged when foreign-owned firms are excluded but no statistical significance is observed. Consistent with Figure 1, one broadly observes negative year effects, relative to 2012, in years coinciding with the global recession, albeit that statistical significance is sporadic. These specifications present little evidence that changes in employment were linked to DSL availability in our sample.

To investigate heterogeneity in the results across firm types, we use Eurostat/NACE technological intensity ratings. The ratings are a standard, pan-European tool used to group firms whose production processes require particular levels of knowledge and technology. A breakdown of the six relevant categories along with a sample list of associated economic activities is outlined in Appendix A. The potential for DSL effects to be mediated by education is assessed 
only through interaction terms in these models as there are insufficient observations for subgroup analyses. The results are presented in Table 3.

Table 2. Fixed effects panel regressions.

\begin{tabular}{|c|c|c|c|c|c|c|}
\hline & \multicolumn{6}{|c|}{ Dependent Variable: Proportional Change in FTE Employment } \\
\hline & \multicolumn{3}{|c|}{ Full Sample } & \multicolumn{3}{|c|}{ Irish Owned Firms } \\
\hline & (1) & $(2)$ & (3) & (4) & $(5)$ & $(6)$ \\
\hline & All & $\mathbf{L E D}^{\mathbf{a}}$ & HED $^{b}$ & All & $\mathbf{L E D}^{\mathbf{c}}$ & HED $^{d}$ \\
\hline \multirow[t]{2}{*}{ Lagged DSL Status } & $0.0444 *$ & 0.0214 & -0.00415 & 0.0408 & 0.0208 & -0.0102 \\
\hline & $(0.0262)$ & $(0.0139)$ & $(0.0143)$ & $(0.0280)$ & $(0.0145)$ & $(0.0155)$ \\
\hline \multirow[t]{2}{*}{ DSL Lag $\times$ Degree } & -0.279 & & & -0.279 & & \\
\hline & $(0.198)$ & & & $(0.215)$ & & \\
\hline \multicolumn{7}{|l|}{ Year Effects } \\
\hline \multirow[t]{2}{*}{2007} & $0.0592 * * *$ & $0.0539 * * *$ & $0.0628 * * *$ & $0.0598 * * *$ & $0.0543 * * *$ & $0.0638 * * *$ \\
\hline & $(0.00614)$ & $(0.00978)$ & $(0.00789)$ & $(0.00673)$ & $(0.0106)$ & $(0.00874)$ \\
\hline \multirow[t]{2}{*}{2008} & -0.00360 & -0.00438 & -0.00329 & -0.00658 & -0.00844 & -0.00551 \\
\hline & $(0.00597)$ & $(0.00967)$ & $(0.00759)$ & $(0.00654)$ & $(0.0104)$ & $(0.00843)$ \\
\hline \multirow[t]{2}{*}{2009} & $-0.0705 * * *$ & $-0.0656^{* * *}$ & $-0.0737 * * *$ & $-0.0695 * * *$ & $-0.0645 * * *$ & $-0.0730 * * *$ \\
\hline & $(0.00579)$ & $(0.00953)$ & $(0.00728)$ & $(0.00635)$ & $(0.0103)$ & $(0.00807)$ \\
\hline \multirow[t]{2}{*}{2010} & -0.00388 & -0.0122 & 0.00141 & -0.00598 & -0.0158 & 0.000580 \\
\hline & $(0.00583)$ & $(0.00931)$ & $(0.00748)$ & (0.00639) & $(0.0100)$ & $(0.00829)$ \\
\hline \multirow[t]{2}{*}{2011} & $0.0123^{* *}$ & 0.00196 & $0.0188 * *$ & $0.0114^{*}$ & -0.00106 & $0.0196 * *$ \\
\hline & $(0.00588)$ & (0.00949) & $(0.00749)$ & (0.00641) & $(0.0101)$ & $(0.00828)$ \\
\hline 2012 & [ref] & [ref] & [ref] & [ref] & [ref] & [ref] \\
\hline \multirow[t]{2}{*}{2013} & $0.0143 * *$ & 0.0148 & $0.0140 *$ & $0.0220 * * *$ & $0.0179 *$ & $0.0245^{* * * *}$ \\
\hline & $(0.00592)$ & (0.00978) & $(0.00744)$ & $(0.00652)$ & $(0.0106)$ & $(0.00827)$ \\
\hline \multirow[t]{2}{*}{2014} & $0.0101 *$ & $0.0195 * *$ & 0.00443 & $0.0162 * *$ & $0.0238 * *$ & 0.0113 \\
\hline & $(0.00573)$ & $(0.00972)$ & $(0.00707)$ & $(0.00632)$ & $(0.0105)$ & $(0.00787)$ \\
\hline \multirow[t]{2}{*}{ Constant } & $0.0186^{*}$ & -0.00617 & $0.0284 * *$ & 0.0189 & -0.00454 & $0.0296 * *$ \\
\hline & $(0.0111)$ & $(0.0137)$ & $(0.0138)$ & $(0.0117)$ & $(0.0143)$ & $(0.0149)$ \\
\hline Fixed Effects & "Yes & Yes & Yes & Yes & Yes & 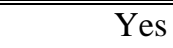 \\
\hline Observations & 40,693 & 15,699 & 24,994 & 35,531 & 14,190 & 21,341 \\
\hline Firms & 6,517 & 2,468 & 4,049 & 5,723 & 2,244 & 3,479 \\
\hline Within R2 & 0.0151 & 0.0138 & 0.0164 & 0.0149 & 0.0137 & 0.0163 \\
\hline
\end{tabular}

Notes: ${ }^{a}$ Lower education sample (below median for firms with DSL status change). ${ }^{b}$ Higher education sample (above median for firms with DSL status change). Errors allow for clustering at the firm level. ${ }^{*} \mathrm{p}<0.1$; $* * \mathrm{p}<0.05 ; * * * \mathrm{p}<0.01$

In services sectors, we find no statistically significant relationship between DSL, or its interaction with education, and employment. Across manufacturing sectors, the only result which returns with statistical significance is that of the high-technology manufacturing (HTM) category. Here, DSL shows signs of promoting employment growth. Offsetting this, however, is a larger negative coefficient on the education interaction which suggests that rather than complementing high skilled labour, broadband is acting as a substitute. While surprising in the context of the existing literature, it may be intuitive that among this group of high technology firms, labour could be substituted with technological solutions. A significant caveat to this result is that relatively few firms in this sub-sample experience a change in DSL availability in our period of analysis. This may suggest the observed significance is an artefact of our data.

Appendix B includes other specifications aimed at testing the stability of the coefficients. First, we test for heterogeneity across firm sizes with a split in the sample at a median of 20 FTE employees. Similarly, we present a specification that includes only data pertaining to the years prior to 2012. After this time, the variation in DSL availability was significantly reduced since the deployment of first generation broadband had been completed. We also address the possibility that firms in urban and rural areas may respond differently to the expansion of DSL 
availability. We divide the sample into two by geography. An 'urban' category includes firms in all counties that contain an urban centre designated as a city, and all other firms are categorised as 'non-urban'. The DSL coefficients lack statistical significance under each of these checks.

Table 3. Fixed effects models by Eurostat-NACE technological intensity ratings.

\begin{tabular}{|c|c|c|c|c|c|c|}
\hline & \multicolumn{6}{|c|}{ Dependent Variable: Proportional Change in FTE Employment } \\
\hline & \multicolumn{4}{|c|}{ Manufacturing } & \multicolumn{2}{|c|}{ Services } \\
\hline & $\begin{array}{c}(1) \\
\text { LTM }^{\mathbf{a}}\end{array}$ & $\begin{array}{c}(2) \\
\text { MLTM }^{\mathbf{b}}\end{array}$ & $\begin{array}{c}(3) \\
\text { MHTMc }^{c}\end{array}$ & $\begin{array}{c}(4) \\
\text { HTM }^{\mathbf{d}}\end{array}$ & $\begin{array}{c}(5) \\
\text { LKIS }^{\mathbf{e}}\end{array}$ & $\begin{array}{c}(6) \\
\text { KIS }^{\mathbf{f}}\end{array}$ \\
\hline Lagged DSL & $\begin{array}{l}-0.0248 \\
(0.0425)\end{array}$ & $\begin{array}{c}-0.00520 \\
(0.0603)\end{array}$ & $\begin{array}{l}0.00508 \\
(0.0739)\end{array}$ & $\begin{array}{c}0.623 * * * \\
(0.229)\end{array}$ & $\begin{array}{c}-0.00882 \\
(0.105)\end{array}$ & $\begin{array}{c}0.0555 \\
(0.0618)\end{array}$ \\
\hline DSL Lag $\times$ Degree & $\begin{array}{c}0.265 \\
(0.331) \\
\end{array}$ & $\begin{array}{c}0.168 \\
(0.512) \\
\end{array}$ & $\begin{array}{r}-0.0189 \\
(0.501) \\
\end{array}$ & $\begin{array}{c}-3.474 * * * \\
(1.315) \\
\end{array}$ & $\begin{array}{c}0.297 \\
(0.608) \\
\end{array}$ & $\begin{array}{c}-0.537 \\
(0.399) \\
\end{array}$ \\
\hline \multicolumn{7}{|l|}{ Year Effects } \\
\hline 2007 & $\begin{array}{c}0.0394 * * * \\
(0.00986)\end{array}$ & $\begin{array}{c}0.0577 * * * \\
(0.0139)\end{array}$ & $\begin{array}{c}0.0120 \\
(0.0157)\end{array}$ & $\begin{array}{l}0.0492 * \\
(0.0282)\end{array}$ & $\begin{array}{c}0.0515^{* *} \\
(0.0239)\end{array}$ & $\begin{array}{c}0.105 * * * \\
(0.0154)\end{array}$ \\
\hline 2008 & $\begin{array}{c}-0.0349 * * * \\
(0.00989)\end{array}$ & $\begin{array}{l}-0.0166 \\
(0.0135)\end{array}$ & $\begin{array}{c}-0.0469 * * * \\
(0.0160)\end{array}$ & $\begin{array}{c}0.0151 \\
(0.0273)\end{array}$ & $\begin{array}{c}0.0283 \\
(0.0247)\end{array}$ & $\begin{array}{c}0.0352 * * \\
(0.0138)\end{array}$ \\
\hline 2009 & $\begin{array}{c}-0.0671 * * * \\
(0.00985)\end{array}$ & $\begin{array}{c}-0.122 * * * \\
(0.0132)\end{array}$ & $\begin{array}{c}-0.129 * * * \\
(0.0159)\end{array}$ & $\begin{array}{c}-0.0572 * * \\
(0.0234)\end{array}$ & $\begin{array}{l}-0.0293 \\
(0.0230)\end{array}$ & $\begin{array}{c}-0.0439 * * * \\
(0.0131)\end{array}$ \\
\hline 2010 & $\begin{array}{l}-0.0231 * * \\
(0.00985)\end{array}$ & $\begin{array}{c}-0.00916 \\
(0.0139)\end{array}$ & $\begin{array}{l}-0.0220 \\
(0.0172)\end{array}$ & $\begin{array}{c}0.0452 \\
(0.0274)\end{array}$ & $\begin{array}{l}-0.0211 \\
(0.0204)\end{array}$ & $\begin{array}{l}0.0242 * \\
(0.0131)\end{array}$ \\
\hline 2011 & $\begin{array}{c}-0.00923 \\
(0.00976) \\
\text { [ref] }\end{array}$ & $\begin{array}{c}0.0196 \\
(0.0141) \\
{[\mathrm{ref}]}\end{array}$ & $\begin{array}{c}0.00987 \\
(0.0171) \\
\text { [ref] }\end{array}$ & $\begin{array}{c}-0.00922 \\
(0.0261) \\
{[\mathrm{ref}]}\end{array}$ & $\begin{array}{c}-0.0182 \\
(0.0209) \\
\text { [ref] }\end{array}$ & $\begin{array}{c}0.0400 * * * \\
(0.0131) \\
{[\mathrm{ref}]}\end{array}$ \\
\hline 2013 & $\begin{array}{c}0.00584 \\
(0.00988)\end{array}$ & $\begin{array}{c}0.0311 * * \\
(0.0141)\end{array}$ & $\begin{array}{c}0.0180 \\
(0.0187)\end{array}$ & $\begin{array}{l}-0.0181 \\
(0.0235)\end{array}$ & $\begin{array}{l}0.00127 \\
(0.0241)\end{array}$ & $\begin{array}{l}0.00994 \\
(0.0125)\end{array}$ \\
\hline 2014 & $\begin{array}{c}0.0122 \\
(0.00950)\end{array}$ & $\begin{array}{c}0.0521 * * * \\
(0.0136)\end{array}$ & $\begin{array}{l}-0.0141 \\
(0.0157)\end{array}$ & $\begin{array}{c}-0.0511 * * \\
(0.0217)\end{array}$ & $\begin{array}{c}0.0166 \\
(0.0210)\end{array}$ & $\begin{array}{c}-0.00479 \\
(0.0132)\end{array}$ \\
\hline Constant & $\begin{array}{l}0.00629 \\
(0.0160)\end{array}$ & $\begin{array}{l}-0.0224 \\
(0.0253)\end{array}$ & $\begin{array}{c}0.0382 \\
(0.0290)\end{array}$ & $\begin{array}{c}0.0372 \\
(0.0662)\end{array}$ & $\begin{array}{l}-0.0163 \\
(0.0323)\end{array}$ & $\begin{array}{c}0.0741 * * \\
(0.0293)\end{array}$ \\
\hline Fixed Effects & Yes & Yes & Yes & Yes & Yes & Yes \\
\hline Observations & 11,463 & 6,480 & 4,647 & 2,105 & 3,202 & 10,200 \\
\hline Firms & 1,776 & 989 & 712 & 333 & 504 & 1,789 \\
\hline Within R2 & 0.0168 & 0.0454 & 0.0328 & 0.0212 & 0.00694 & 0.0148 \\
\hline
\end{tabular}

Notes: aLow technology manufacturing; ${ }^{\mathrm{a}}$ Medium-low technology manufacturing; ${ }^{\mathrm{C}}$ Medium-high technology manufacturing; ${ }^{\mathrm{d}}$ High technology manufacturing; ${ }^{\mathrm{e}}$ Less knowledge intensive services; ${ }^{\mathrm{f}}$ Knowledge intensive services. Errors clustered at firm level. $* \mathrm{p}<0.1 ; * * \mathrm{p}<0.05 ; * * * \mathrm{p}<0.01$

\section{Concluding remarks}

We find little evidence of any association between DSL rollout and employment growth within existing Irish firms during this period, even when educational attainment is taken into account. This finding is in contrast with evidence from other jurisdictions suggesting that broadband tends to be complementary with highly educated labour, further emphasising the context-sensitivity of the effects broadband has on firms. Our analysis has some limitations that must be noted. The reliance on Euclidean distance to assess the availability of DSL likely implies at least some measurement error. The accuracy of our proxy in mirroring the exact locations of underground cable infrastructure cannot be tested in the data. Similarly, our measure of educational attainment is based on area averages. This may not fully reflect the skill-sets of a particular firm's employees as workers could be chosen from a labour pool that is not bounded geographically by the local electoral division or characterised by its spatial averages. These measures do, however, represent the best feasible approximations given the currently available 
data. Furthermore, we cannot be certain as to whether or not any firms in our sample had internet access through technologies other than DSL. However, as evidenced by additional survey data presented in Figure C1 (Appendix C), the majority of enterprises who used a broadband service in Ireland at the time did so through a DSL connection.

\section{Acknowledgements}

The authors are grateful to the editor and an anonymous reviewer for helpful comments, to the Irish Government's Department of Business, Enterprise and Innovation for permitting access to micro-data from their Annual Employment Survey and to Eir for access to data on the rollout of DSL services across Ireland. Funding was received from the ESRI Programme of Research in Communications, which is in turn supported by the Commission for Communications Regulation and the Department of Communications, Climate Action and Environment. The funders played no role in the design or implementation of the study or in the preparation of this paper. The decision to submit this work for publication was our own, and the usual disclaimer applies.

\section{References}

Akerman, A., Gaarder, I. and Mogstad, M. (2015) The Skill Complementarity of Broadband Internet, The Quarterly Journal of Economics, 130(4), 1781-1824.

Atasoy, H. (2013) The Effects of Broadband Internet Expansion on Labor Market Outcomes, ILR Review, 66(2), 315-45.

Bertschek, I., Briglauer, W., Hüschelrath, K., Kauf, B, and Niebel, T. (2015), The Economic Impacts of Broadband Internet: A Survey, Review of Network Economics, 14(4), 201-227.

Czernich, N. (2014) Does Broadband Internet Reduce the Unemployment Rate? Evidence for Germany, Information Economics and Policy, 29, 32-45.

Czernich, N., Falck, O., Kretschmer, T. and Woessmann, L. (2011) Broadband Infrastructure and Economic Growth, The Economic Journal, 121(552): 505-532.

Ivus, O. and Boland, M. (2015) The Employment and Wage Impact of Broadband Deployment in Canada', Canadian Journal of Economics, 48(5), 1803-1830.

Kolko, J. (2012) Broadband and Local Growth, Journal of Urban Economics, 71(1): 100-113. 


\section{Appendix A - Eurostat - NACE technology ratings}

Table Al. Eurostat - NACE technology ratings.

\begin{tabular}{|c|c|c|}
\hline Technological Intensity & $\overline{\text { Code }}$ & Sample Economic Activities \\
\hline $\begin{array}{l}\text { Knowledge-intensive } \\
\text { services }\end{array}$ & KIS & $\begin{array}{l}\text { Water transport; Air transport; } \\
\text { Publishing activities; } \\
\text { Programming and broadcasting activities; } \\
\text { Computer programming, consultancy and related activities; } \\
\text { Telecommunications; } \\
\text { Financial and insurance activities; } \\
\text { Security and investigation activities; } \\
\text { Public administration; Education; Human Health. }\end{array}$ \\
\hline $\begin{array}{l}\text { Less knowledge-intensive } \\
\text { intensive services }\end{array}$ & LKIS & $\begin{array}{l}\text { Wholesale and retail trade; } \\
\text { Accommodation and food service activities; } \\
\text { Repair of motor vehicles and motorcycles; } \\
\text { Real estate, rental and leasing activities; } \\
\text { Office administration and office support; } \\
\text { Travel agency, tour operator reservation services. }\end{array}$ \\
\hline $\begin{array}{l}\text { High-technology } \\
\text { manufacturing }\end{array}$ & HTM & $\begin{array}{l}\text { Manufacture of pharmaceutical products; } \\
\text { Manufacture of computer, electronic and optical products. }\end{array}$ \\
\hline $\begin{array}{l}\text { Medium-high-technology } \\
\text { manufacturing }\end{array}$ & MHTM & $\begin{array}{l}\text { Manufacture of chemicals and chemical products; } \\
\text { Manufacture of electrical equipment; } \\
\text { Manufacture of motor vehicles. }\end{array}$ \\
\hline $\begin{array}{l}\text { Medium-low-technology } \\
\text { manufacturing }\end{array}$ & MLTM & $\begin{array}{l}\text { Manufacture of coke and refined petroleum products; } \\
\text { Manufacture of rubber and plastic; } \\
\text { Repair and installation of machinery and equipment. }\end{array}$ \\
\hline $\begin{array}{l}\text { Low-technology } \\
\text { manufacturing }\end{array}$ & LTM & $\begin{array}{l}\text { Manufacture of food products and beverages; } \\
\text { Manufacture of textiles and apparel; } \\
\text { Reproduction of recorded media; } \\
\text { Manufacture of paper products; } \\
\text { Manufacture of furniture; Other manufacturing. }\end{array}$ \\
\hline
\end{tabular}




\section{Appendix B - Additional specifications}

Table B1. Fixed effect panel regressions by firms size.

\begin{tabular}{|c|c|c|c|c|c|c|}
\hline & \multicolumn{6}{|c|}{ Dependent Variable: Proportional Change in FTE Employment } \\
\hline & \multicolumn{3}{|c|}{ Median FTE $<20$} & \multicolumn{3}{|c|}{ Median FTE $>20$} \\
\hline & (1) & (2) & $(3)$ & (4) & $(5)$ & $(6)$ \\
\hline & All & $\mathbf{L E D}^{\mathbf{a}}$ & HED $^{b}$ & All & $\mathbf{L E D}^{\mathbf{a}}$ & HED $^{b}$ \\
\hline Lagged DSL Status & $\begin{array}{r}0.0370 \\
(0.0327)\end{array}$ & $\begin{array}{r}0.0249 \\
(0.0171)\end{array}$ & $\begin{array}{r}-0.00228 \\
(0.0187)\end{array}$ & $\begin{array}{r}0.0662 \\
(0.0409)\end{array}$ & $\begin{array}{r}0.0175 \\
(0.0234)\end{array}$ & $\begin{array}{c}-0.00828 \\
(0.0186)\end{array}$ \\
\hline DSL Lag x Degree & $\begin{array}{r}-0.206 \\
(0.252) \\
\end{array}$ & & & $\begin{array}{r}-0.462 \\
(0.290) \\
\end{array}$ & & \\
\hline \multicolumn{7}{|l|}{ Year Effects } \\
\hline 2007 & $\begin{array}{r}0.0669 * * * \\
(0.00813)\end{array}$ & $\begin{array}{r}0.0641 * * * \\
(0.0128)\end{array}$ & $\begin{array}{r}0.0689 * * * \\
(0.0105)\end{array}$ & $\begin{array}{r}0.0432 * * * \\
(0.00850)\end{array}$ & $\begin{array}{r}0.0326 * * \\
(0.0135)\end{array}$ & $\begin{array}{r}0.0495 * * * \\
(0.0109)\end{array}$ \\
\hline 2008 & $\begin{array}{r}-0.00152 \\
(0.00784)\end{array}$ & $\begin{array}{r}-0.00371 \\
(0.0124)\end{array}$ & $\begin{array}{r}-0.000211 \\
(0.0101)\end{array}$ & $\begin{array}{r}-0.00741 \\
(0.00846)\end{array}$ & $\begin{array}{r}-0.00353 \\
(0.0146)\end{array}$ & $\begin{array}{r}-0.0102 \\
(0.0103)\end{array}$ \\
\hline 2009 & $\begin{array}{r}-0.0574 * * * \\
(0.00757)\end{array}$ & $\begin{array}{r}-0.0542 * * * \\
(0.0122)\end{array}$ & $\begin{array}{r}-0.0597 * * * \\
(0.00964)\end{array}$ & $\begin{array}{r}-0.0986^{* * * *} \\
(0.00819)\end{array}$ & $\begin{array}{r}-0.0906 * * * \\
(0.0141)\end{array}$ & $\begin{array}{r}-0.104 * * * \\
(0.0100)\end{array}$ \\
\hline 2010 & $\begin{array}{r}-0.00520 \\
(0.00759)\end{array}$ & $\begin{array}{r}-0.0156 \\
(0.0120)\end{array}$ & $\begin{array}{r}0.00150 \\
(0.00980)\end{array}$ & $\begin{array}{r}-0.000572 \\
(0.00836)\end{array}$ & $\begin{array}{r}-0.00394 \\
(0.0136)\end{array}$ & $\begin{array}{r}0.00139 \\
(0.0106)\end{array}$ \\
\hline 2011 & $\begin{array}{l}0.0153 * * \\
(0.00764)\end{array}$ & $\begin{array}{r}-0.00562 \\
(0.0121)\end{array}$ & $\begin{array}{r}0.0288 * * * \\
(0.00987)\end{array}$ & $\begin{array}{r}0.00556 \\
(0.00844)\end{array}$ & $\begin{array}{r}0.0200 \\
(0.0145)\end{array}$ & $\begin{array}{r}-0.00291 \\
(0.0104)\end{array}$ \\
\hline 2012 & [ref] & [ref] & [ref] & [ref] & [ref] & [ref] \\
\hline 2013 & $\begin{array}{r}0.0221 * * * \\
(0.00778)\end{array}$ & $\begin{array}{r}0.0200 \\
(0.0128)\end{array}$ & $\begin{array}{c}0.0234 * * \\
(0.00981)\end{array}$ & $\begin{array}{r}-0.00223 \\
(0.00826)\end{array}$ & $\begin{array}{r}0.00317 \\
(0.0137)\end{array}$ & $\begin{array}{r}-0.00555 \\
(0.0104)\end{array}$ \\
\hline 2014 & $\begin{array}{r}0.0200 * * * \\
(0.00775)\end{array}$ & $\begin{array}{l}0.0248 * \\
(0.0130)\end{array}$ & $\begin{array}{r}0.0171 * \\
(0.00962)\end{array}$ & $\begin{array}{r}-0.0104 \\
(0.00715)\end{array}$ & $\begin{array}{r}0.00837 \\
(0.0125)\end{array}$ & $\begin{array}{r}-0.0215^{* *} \\
(0.00867)\end{array}$ \\
\hline Constant & $\begin{array}{r}0.00661 \\
(0.0140) \\
\end{array}$ & $\begin{array}{r}-0.0137 \\
(0.0166) \\
\end{array}$ & $\begin{array}{r}0.0160 \\
(0.0177) \\
\end{array}$ & $\begin{array}{r}0.0434 * * * \\
(0.0163) \\
\end{array}$ & $\begin{array}{r}0.00727 \\
(0.0240)\end{array}$ & $\begin{array}{r}0.0551 * * * \\
(0.0190) \\
\end{array}$ \\
\hline Fixed Effects & Yes & Yes & Yes & Yes & Yes & 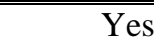 \\
\hline Observations & 27,978 & 10,969 & 17,009 & 12,715 & 4,730 & 7,985 \\
\hline Firms & 4,711 & 1,802 & 2,909 & 1,806 & 666 & 1,140 \\
\hline Within R2 & 0.0121 & 0.0121 & 0.0129 & 0.0301 & 0.0268 & 0.0333 \\
\hline
\end{tabular}

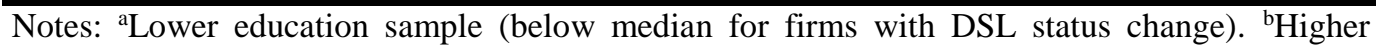
education sample (above median for firms with DSL status change). Errors allow for clustering at the firm level. $* \mathrm{p}<0.1 ; * * \mathrm{p}<0.05 ; * * * \mathrm{p}<0.01$.

Table B2. DSL Coefficients from Additional Models.

\begin{tabular}{|c|c|c|c|c|c|}
\hline & $\begin{array}{r}\text { Lagged } \\
\text { DSL Status }\end{array}$ & $\overline{\text { SE }}$ & $\begin{array}{r}\text { Lagged DSL } \\
x \text { Degree }\end{array}$ & $\overline{\mathrm{SE}}$ & $\overline{\overline{\text { Obs }}}$ \\
\hline \multicolumn{6}{|l|}{ Pre-2012 Observations } \\
\hline Full Sample & 0.0344 & $(0.0322)$ & -0.206 & $(0.234)$ & 25,922 \\
\hline Below Median Education Level & 0.0159 & $(0.0183)$ & & & 10,130 \\
\hline Above Median Education Level & 0.000858 & $(0.0196)$ & & & 15,792 \\
\hline \multicolumn{6}{|l|}{ Urban Vs. Non-urban Counties } \\
\hline \multicolumn{6}{|l|}{ Urban Counties } \\
\hline All & 0.0699 & $(0.0496)$ & -0.242 & $(0.310)$ & 14,809 \\
\hline Below Median Education Level & 0.0472 & $(0.0344)$ & & & 3,646 \\
\hline Above Median Education Level & 0.0260 & $(0.0233)$ & & & 11,163 \\
\hline \multicolumn{6}{|l|}{ Non-urban Counties } \\
\hline All & 0.0516 & $(0.0326)$ & $-0.478 *$ & $(0.273)$ & 25,884 \\
\hline Below Median Education Level & 0.0119 & $(0.0141)$ & & & 12,053 \\
\hline Above Median Education Level & -0.0271 & $(0.0179)$ & & & 13,831 \\
\hline
\end{tabular}

Notes: Errors are clustered at the firm level. ${ }^{*} \mathrm{p}<0.1 ; * * \mathrm{p}<0.05 ; * * * \mathrm{p}<0.01$ 


\section{Appendix C - Broadband connections in Irish firms}

Figure C1. Enterprises in Ireland who report having a DSL connection.

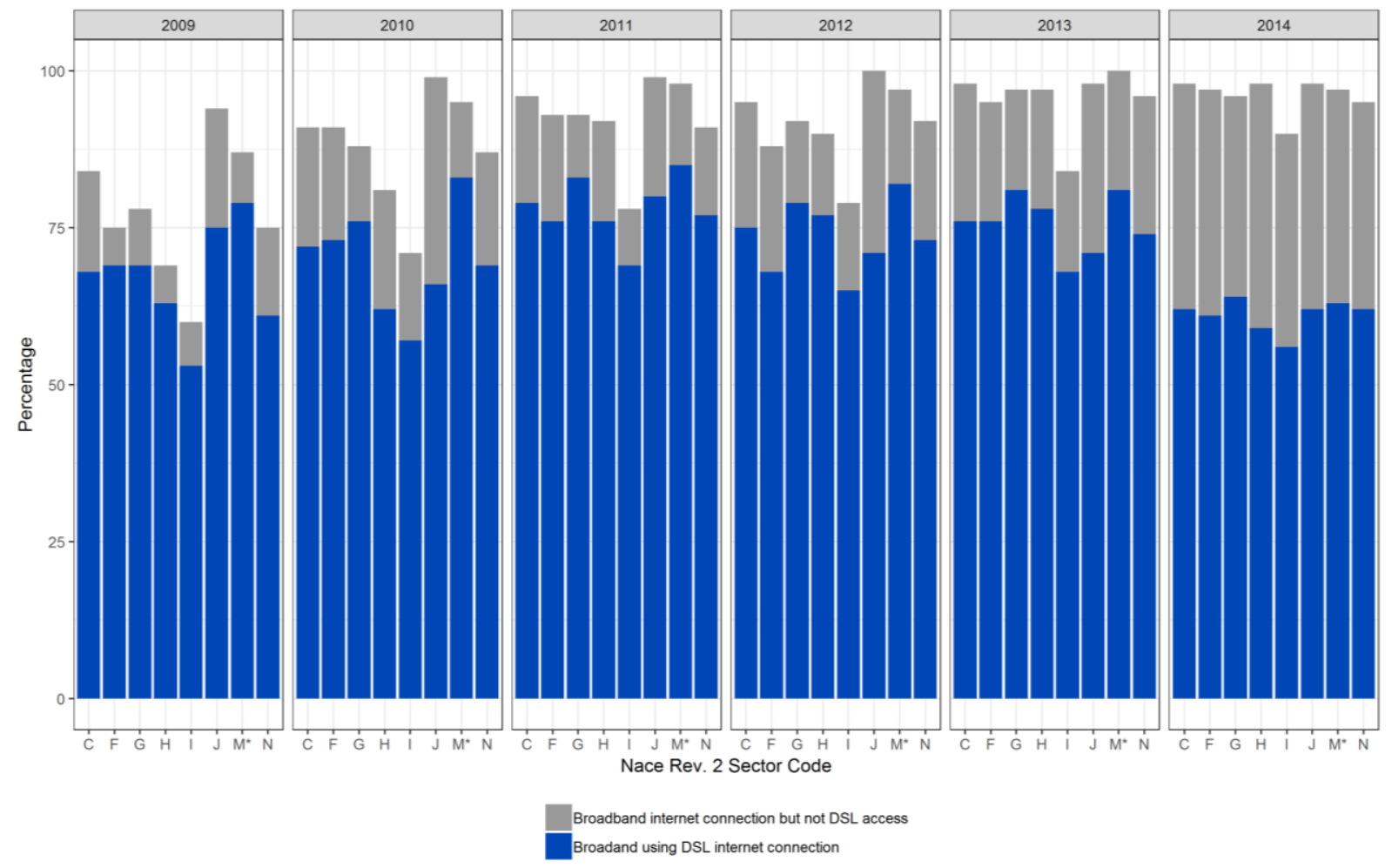

Source: cso Information Society Statstics - Enterprises
te: * Category M (Professional, Scientific \& Technical) here excludes veterinary activities. 